\title{
Donor support to electoral cycles
}

Siân Herbert

GSDRC \& K4D, University of Birmingham

24 February 2021

\section{Questions}

What are the stages of an election cycle? How have donors been providing electoral assistance to developing countries throughout the cycle?

\section{Contents}
1. Summary
2. The election cycle
3. Donor support to electoral cycles
4. References

The K4D helpdesk service provides brief summaries of current research, evidence, and lessons learned. Helpdesk reports are not rigorous or systematic reviews; they are intended to provide an introduction to the most important evidence related to a research question. They draw on a rapid deskbased review of published literature and consultation with subject specialists. 


\section{Summary}

This rapid literature review explains the stages of an election cycle, and how donors provide support to electoral cycles. It draws mainly on policy guidance websites and papers due to the questions of this review and the level of analysis taken (global-level, donor-level). It focuses on publications from the last five years, and/or current/forthcoming donor strategies.

The electoral cycle and its stages are well established policy concepts for which there is widespread acceptance and use. Donor support to electoral cycles (through electoral assistance and electoral observation) is extremely widespread, and the dominant donors in this area are the multilateral organisations like the United Nations (UN) and the European Union (EU), and also the United States (US). While almost all bilateral donors also carry out some work in this area, "almost all major electoral support programmes are provided jointly with international partners" (DFID, 2014, p.5). Bilateral donors may provide broader support to democratic governance initiatives, which may not be framed as electoral assistance, but may contribute to the wider enabling environment. All of the donors reviewed in this query emphasise that their programmes are designed according to the local context and needs, and thus, beyond the big actors - EU, UN and US, there is little overarching information on what the donors do in this area. ${ }^{1}$

While there is a significant literature base in the broad area of electoral support, it tends to be focussed at the country, programme, or thematic, level, rather than at the global, or donor, level taken by this paper. There was a peak in global-level publications on this subject around 2006, the year the electoral cycle model was published by the European Commission, International Institute for Democracy and Electoral Assistance (International IDEA), and United Nations Development Programme (UNDP). This review concludes by providing examples of the electoral assistance work carried out by five donors (UN, EU, US, UK and Germany).

Key findings from this review include:

The electoral cycle is a conceptual and planning tool that was developed to ensure that electoral assistance is consistent, integrated, long-term, and proactive, rather than event-based, siloed, short-term, and responsive (ACE, n.d.a; Fath-Lihic \& Brancati, 2017, p.6). Through the election cycle lens, the election period is seen as a phase in a longer-term process of democratisation, which is made up of many interdependent stages and building blocks, and where the breakdown of one stage can negatively affect another (ACE, n.d.a). The tool helps governments and donors plan and allocate resources in a timely way and to ensure that activities and phases are not forgotten.

\footnotetext{
${ }^{1}$ Section 3 collates information from the donor agencies provided on their websites, and in some cases, from their strategy documents. In the time available, it was not possible to verify if the donors are indeed engaging in the areas they set as broad priorities.

This rapid review carried out searches on the donors listed as working in the area of electoral assistance by Norris (2017) - starting with the two biggest multilateral donors, before moving onto the bilateral donors. However, beyond the US, this rapid review found little high-level/strategic-level information about bilateral donor electoral assistance. The UK and Germany have been included as examples, despite limited information. Similar rapid searches carried out for Canada and the Netherlands yielded little information. Further work could focus on donor support in a few case study countries, as more specific detail is available at the country level, and as all donors agree that their programmes are designed according to the local context.
} 
There are some broad phases in the cycle that are relatively universal (for countries that have elections), yet the detail of each election cycle differs according to the context - e.g. what kind of elections are happening; when, how they coincide with other elections, the legal context, etc. (ACE, n.d.). The broad stages are: pre-election period; election period, and post-election period. Within these three broad stages, there are a number of sub-phases: Pre-election period (legal phase, planning and implementation, training and education, voter registration, and electoral campaign); election period (voting operations and election day, and verification of results); and post-election period. The election cycle tool can be applied to specific thematic issues within an election cycle to help plan activities - such as gender mainstreaming or supporting technology needs throughout the electoral cycle.

Electoral assistance includes legal, operational, and logistical support to electoral laws, procedures, and institutions. Electoral assistance programmes cover a broad range of areas, including: electoral administration; the review and reform of constitutional principles; voter registration; media training; civic education; engagement of underrepresented groups; and electoral security; etc. Electoral assistance tends to come under programming in the areas of Sustainable Development Goal (SDG) 16 'peaceful and inclusive societies', ${ }^{2}$ and/or under workstreams related to democracy, human rights and governance, with thematic, geographic and modality priorities varying across donor agencies and according to the context (Norris, 2017). Key multilateral actors that fund and/or implement electoral assistance include: UN, EU, Organization for Security and Cooperation in Europe (OSCE), and the African Union. Important bilateral actors include: US; Germany, UK, and the Netherlands. They work with a dense network of local and international actors in implementation, advocacy, research and monitoring (Norris, 2017). Electoral assistance programmes may be initiated with electoral needs assessment missions.

\section{The election cycle}

The electoral cycle is a conceptual and planning tool that was developed to ensure that electoral assistance is consistent, integrated, long-term, and proactive, rather than eventbased, siloed, short-term, and responsive (ACE, n.d.a; Fath-Lihic \& Brancati, 2017, p.6; DFID, 2014). It was initially developed by the European Commission, International IDEA, and UNDP in 2006, and is now widely used, with slight variations in the graphic used (ACE, n.d.a). It emerged in response to the challenges around short-term and rushed support to elections, where elections were treated as one-off events "without adequate planning and preparation for complex logistical tasks such as preparing accurate electoral registers and mobilizing citizens through civic education, and with bottlenecks, waste, and inefficiencies arising from the sudden influx of development aid" (Norris, 2017, p.37). It also recognised that while electoral assistance had been focussed on the technical aspects of elections, it was not sufficiently focussed on the longer-term institutional and capacity issues (Haider, 2008). The focus on capacity building extends not only to recipient countries but also to donors - to share and learn lessons and best practices, and to better coordinate their interventions, in line with the emergence of the aid effectiveness principles through the Paris agreement (Haider, 2008).

Through the election cycle lens, the election period is seen as a phase in a longer-term process of democratisation, which is made up of many interdependent stages and

2 See - https://sdgs.un.org/goals/goal16 
building blocks, and where the breakdown of one stage can negatively affect another (ACE, n.d.a). The tool helps governments and donors plan and allocate resources in a timely way and to ensure that activities and phases are not forgotten - e.g. so that the post-electoral period is recognised to be a significant moment for institutional growth and not just as gap between elections (ACE, n.d.a). It also highlights how support to electoral processes entails long-term commitment (ACE, n.d.a). Figure 1 shows a visual representation of the electoral cycle, its phases, and tasks per phase.

See: Figure 1: The electoral cycle, Source: European Centre for Electoral Support (n.d.), https://www.eces.eu/en/electoral-cycles-steps-training

\section{Phases}

There are some broad phases that are relatively universal (for countries that have elections), yet the detail of each election cycle differs according to the context - e.g. what kind of elections are happening, when, how they coincide with other elections, the legal context, etc. (ACE, n.d.a). As an example, some countries may have a legally mandated campaign period, while others may not (ACE, n.d.b.). The broad stages - as depicted in Figure 1 - are (ACE, n.d.b):

- Pre-election period

- Election period; and

- Post-election period

Within these three broad stages, there are a number of sub-phases:

- Legal phase

- Planning \& implementation

- Training \& education

- Voter registration

- Electoral campaign

- Voting operations \& election day

- Verification of results

- Post-election

The election cycle tool can also be applied to specific thematic issues within an election cycle to help plan activities - such as gender mainstreaming throughout the electoral cycle (see Figure 2), or supporting technology needs throughout the electoral cycle (see Figure 3). To illustrate how it can be applied in a general way, and then also on specific thematic issues, see Figure 4. International IDEA have made an interactive Online Electoral Cycle tool where the user can find suggested actions and online resources for electoral support according to the actor and 
purpose. ${ }^{3}$ Another useful resource is a table in DFID's (2014, p.12-13) where common election risks and risk factors are mapped onto the election cycle.

Figure 2: Gender mainstreaming interventions throughout the electoral cycle



Source: UNDP \& UN Women (2015, p.54), reproduced with permission

\footnotetext{
${ }^{3}$ See - https://www.idea.int/data-tools/tools/online-electoral-cycle
} 
Figure 3: Relevance of technology throughout the electoral cycle

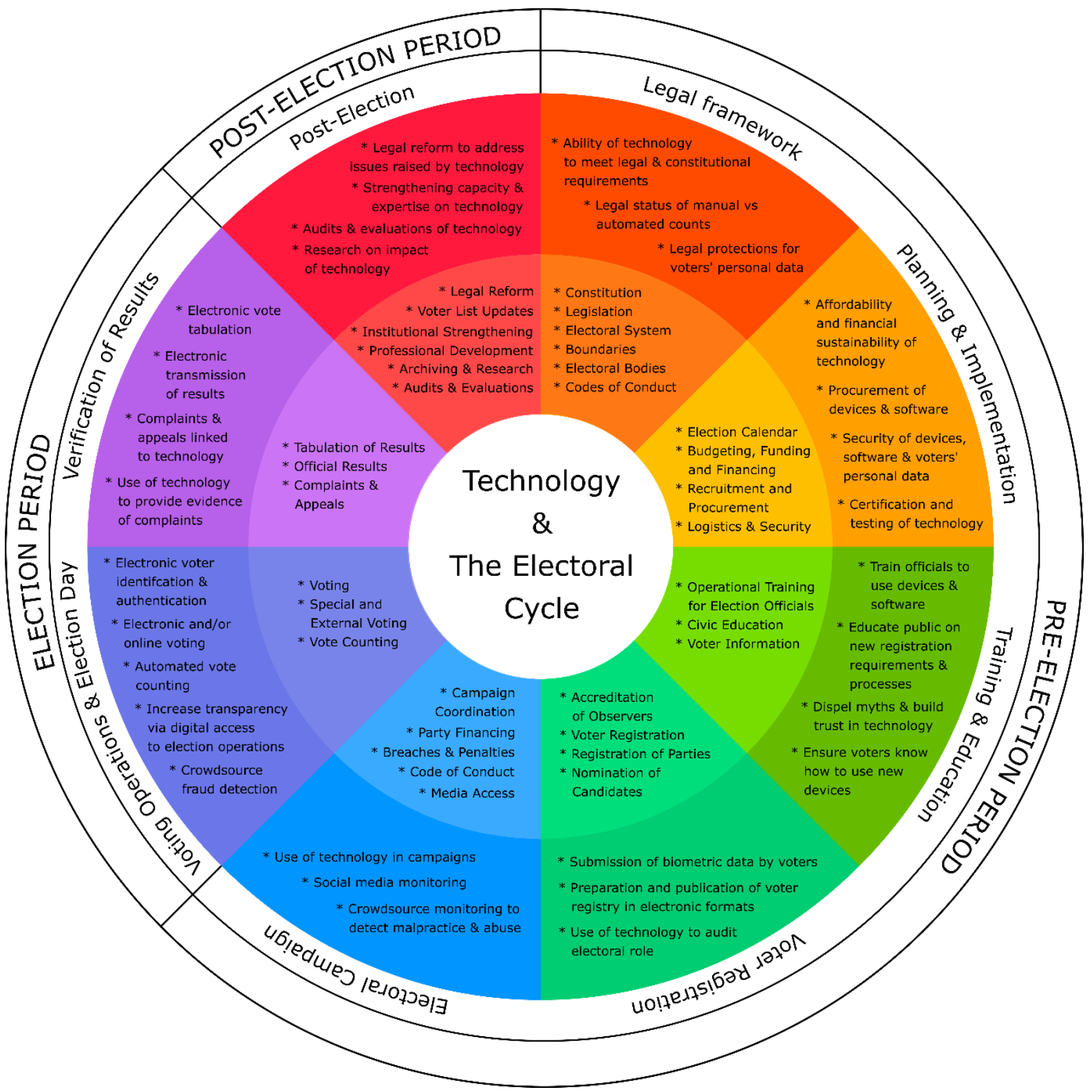

* "The inner wheel lists core activities in each part of the election cycle. The outer wheel identifies how technology is used, and some of the issues it raises, in the corresponding part of the election cycle" (Cheeseman \& Dodsworth, 2019, p.9).

Source: Cheeseman \& Dodsworth (2019, p.9). Reproduced with permission. 


\begin{tabular}{|c|c|c|c|c|}
\hline & & $\begin{array}{l}\text { Electoral cycle } \\
\text { (general) (ACE, n.d.a) }\end{array}$ & $\begin{array}{l}\text { Example: } \\
\text { Promoting } \\
\text { gender equality } \\
\text { and women's } \\
\text { participation } \\
\text { during the } \\
\text { electoral cycle } \\
\text { (UNDP \& UN } \\
\text { Women, 2015; } \\
\text { ACE, n.d.d) }\end{array}$ & $\begin{array}{l}\text { Example: } \\
\text { Supporting } \\
\text { technology needs } \\
\text { during the electoral } \\
\text { cycle (Cheeseman \& } \\
\text { Dodsworth, 2019) }\end{array}$ \\
\hline $\begin{array}{l}\text { ELECTC } \\
\text { STAGES }\end{array}$ & RAL CYCLE & ACTIVITIES/CONSIDE & RATIONS & \\
\hline $\begin{array}{l}\text { Pre- } \\
\text { election } \\
\text { period }\end{array}$ & Legal phase & $\begin{array}{l}\text { Constitution } \\
\text { Legislation } \\
\text { Electoral systems \& } \\
\text { boundaries } \\
\text { Electoral bodies } \\
\text { Codes of conduct }\end{array}$ & $\begin{array}{l}\text { Gender mapping } \\
\text { and policy review } \\
\text { Increase women's } \\
\text { representation: } \\
\text { address gender } \\
\text { discrimination of } \\
\text { candidate } \\
\text { nomination rules \& } \\
\text { electoral law \& } \\
\text { regulations } \\
\text { Increase women's } \\
\text { participation: } \\
\text { target women to } \\
\text { register \& ensure } \\
\text { gender-sensitive } \\
\text { outreach e.g. voter } \\
\text { eligibility rules } \\
\text { around documents }\end{array}$ & $\begin{array}{l}\text { Ability of technology } \\
\text { to meet legal \& } \\
\text { constitutional } \\
\text { requirements } \\
\text { Legal status of } \\
\text { manual vs automatic } \\
\text { counts } \\
\text { Legal protections for } \\
\text { voters' personal data }\end{array}$ \\
\hline & $\begin{array}{l}\text { Planning \& } \\
\text { implementation }\end{array}$ & $\begin{array}{l}\text { Budgeting, funding \& } \\
\text { financing } \\
\text { Election calendar } \\
\text { Recruitment \& } \\
\text { procurements } \\
\text { Logistics \& security }\end{array}$ & $\begin{array}{l}\text { Gender quota laws } \\
\text { for candidates } \\
\text { Political finance } \\
\text { regulations for } \\
\text { women's } \\
\text { candidacies } \\
\text { Gender balance of } \\
\text { staff at all levels, } \\
\text { including polling } \\
\text { staff. Equal } \\
\text { opportunity } \\
\text { recruitment } \\
\text { process, salaries \& } \\
\text { working conditions }\end{array}$ & $\begin{array}{l}\text { Affordability \& } \\
\text { financial sustainability } \\
\text { of technology } \\
\text { Procurement of } \\
\text { devices \& software } \\
\text { Security of devices, } \\
\text { software \& voters' } \\
\text { personal data } \\
\text { Certification \& testing } \\
\text { of technology }\end{array}$ \\
\hline
\end{tabular}




\begin{tabular}{|c|c|c|c|c|}
\hline & & & $\begin{array}{l}\text { Strategies for } \\
\text { family voting \& } \\
\text { violence } \\
\text { prevention } \\
\text { Women } \\
\text { representation in } \\
\text { decision-making }\end{array}$ & \\
\hline & $\begin{array}{l}\text { Training \& } \\
\text { education }\end{array}$ & $\begin{array}{l}\text { Operational training } \\
\text { for election officials } \\
\text { Civic education } \\
\text { Voter information }\end{array}$ & $\begin{array}{l}\text { Targeted voters \& } \\
\text { civic education } \\
\text { Specific } \\
\text { development } \\
\text { capacity initiatives } \\
\text { Use of gender } \\
\text { correct } \\
\text { terminology }\end{array}$ & $\begin{array}{l}\text { Train officials to use } \\
\text { devices \& software } \\
\text { Security of devices, } \\
\text { software \& voters' } \\
\text { personal data } \\
\text { Certification and } \\
\text { testing of technology }\end{array}$ \\
\hline & $\begin{array}{l}\text { Voter } \\
\text { registration }\end{array}$ & $\begin{array}{l}\text { Voters registration } \\
\text { Observers } \\
\text { accreditation } \\
\text { Domestic observers } \\
\text { Parties \& candidates }\end{array}$ & $\begin{array}{l}\text { Access to } \\
\text { administrative } \\
\text { documentation } \\
\text { Repartition \& } \\
\text { access of } \\
\text { registration sites } \\
\text { Access to political } \\
\text { parties' nomination } \\
\text { Voter registration } \\
\text { procedures }\end{array}$ & $\begin{array}{l}\text { Submission of } \\
\text { biometric data by } \\
\text { voters } \\
\text { Preparation \& } \\
\text { publication of voter } \\
\text { registry in electronic } \\
\text { formats } \\
\text { Use of technology to } \\
\text { audit electoral role }\end{array}$ \\
\hline & $\begin{array}{l}\text { Electoral } \\
\text { campaign }\end{array}$ & $\begin{array}{l}\text { Campaign } \\
\text { coordination } \\
\text { Breaches \& penalties } \\
\text { Party financing } \\
\text { Media access code of } \\
\text { conduct }\end{array}$ & $\begin{array}{l}\text { Access to media \& } \\
\text { campaign events } \\
\text { Security conditions } \\
\text { Targeted training } \\
\text { for women } \\
\text { candidates } \\
\text { Possibility to form } \\
\text { women political } \\
\text { grouping }\end{array}$ & $\begin{array}{l}\text { Use of technology in } \\
\text { campaigns } \\
\text { Social media } \\
\text { monitoring } \\
\text { Crowdsource } \\
\text { monitoring to detect } \\
\text { malpractice \& abuse }\end{array}$ \\
\hline $\begin{array}{l}\text { Election } \\
\text { period }\end{array}$ & $\begin{array}{l}\text { Voting } \\
\text { operations \& } \\
\text { election day }\end{array}$ & $\begin{array}{l}\text { Vote counting } \\
\text { Voting } \\
\text { Special \& eternal } \\
\text { voting }\end{array}$ & $\begin{array}{l}\text { Balanced } \\
\text { representation } \\
\text { within polling } \\
\text { stations' } \\
\text { committees }\end{array}$ & $\begin{array}{l}\text { Electronic voter } \\
\text { identification \& } \\
\text { authentication } \\
\text { Electronic and/or } \\
\text { online voting }\end{array}$ \\
\hline
\end{tabular}




\begin{tabular}{|c|c|c|c|}
\hline & & $\begin{array}{l}\text { Polling } \\
\text { procedures, } \\
\text { handbooks \& staff } \\
\text { gender-aware } \\
\text { Special polling } \\
\text { arrangements e.g. } \\
\text { to ensure secrecy } \\
\text { Gender-aware } \\
\text { voter outreach } \\
\text { messages and } \\
\text { images }\end{array}$ & $\begin{array}{l}\text { Automated vote } \\
\text { counting } \\
\text { Increase } \\
\text { transparency via } \\
\text { digital Access to } \\
\text { election operations } \\
\text { Crowdsource fraud } \\
\text { detection }\end{array}$ \\
\hline & $\begin{array}{l}\text { Verification of } \\
\text { results }\end{array}$ & $\begin{array}{l}\text { Conditions of } \\
\text { access to electoral } \\
\text { disputes resolution } \\
\text { mechanisms } \\
\text { Guarantees for fair } \\
\text { remedy }\end{array}$ & $\begin{array}{l}\text { Electronic vote } \\
\text { tabulation } \\
\text { Electronic } \\
\text { transmission of } \\
\text { results } \\
\text { Complaints \& } \\
\text { appeals linked to } \\
\text { technology } \\
\text { Use of technology } \\
\text { Use of technology to } \\
\text { provide evidence of } \\
\text { complaints }\end{array}$ \\
\hline $\begin{array}{l}\text { Post- } \\
\text { election } \\
\text { period }\end{array}$ & Post-election & $\begin{array}{l}\text { Post-election } \\
\text { review \& gender } \\
\text { analysis with sex- } \\
\text { disaggregated } \\
\text { data of voter } \\
\text { registration, } \\
\text { turnout and } \\
\text { candidate } \\
\text { nomination } \\
\text { Targeted } \\
\text { recommendations, } \\
\text { gender policy \& } \\
\text { action plan }\end{array}$ & $\begin{array}{l}\text { Legal reform to } \\
\text { address issues raised } \\
\text { by technology } \\
\text { Strengthening } \\
\text { capacity \& expertise } \\
\text { on technology } \\
\text { Audits \& evaluations } \\
\text { of technology } \\
\text { Research on impact } \\
\text { of technology }\end{array}$ \\
\hline
\end{tabular}

Source: Table compiled from: ACE, n.d.a; UNDP \& UN Women, 2015; ACE, n.d.d; (Cheeseman \& Dodsworth, 2019) 


\section{Donor support to electoral cycles}

\section{Electoral assistance (general)}

Electoral assistance includes legal, operational, and logistical support to electoral laws, procedures, and institutions (Norris, 2017). Electoral assistance programmes typically address areas including: "electoral administration, logistics, budgeting and planning; the review and reform of constitutional principles, electoral laws and regulations; boundary delimitation; voter registration; the electoral use of information and communication technologies; the training and capacity building of electoral officials and other stakeholders such as parties and the media; civic education, information, and engagement, especially the inclusion and participation of underrepresented groups such as women, young people, and ethnic minorities; the role of journalists and the news media; the regulation of political finance; the structure, organization, and funding of political parties; the role of the police and armed forces in providing electoral security and preventing conflict; processes of balloting and vote count facilities; and the role of the judiciary and intermediary bodies in dispute resolution processes" (Norris, 2017, p.34). Electoral assistance tends to come under programming in the areas of democracy, human rights and governance, with thematic, geographic and modality priorities varying across donor agencies, and according to the context (Norris, 2017). Beyond aid, there are other tools that can fall under, or complement, election assistance such as: economic sanctions; diplomatic mediation, and the deployment of peacekeepers or military (Norris, 2017).

The scope and effectiveness of electoral assistance depends on the context, including (ACE, n.d.e):

- The type of election (e.g. national or sub-national, presidential, parliamentary or local);

- The environment in which the election takes place (e.g. post-conflict, transition, third or fourth post-transition/post-independence election);

- Other prevailing conditions (size of electorate, health of the national economy and national funding available for elections, state of voter register and electoral institutions, physical constraints, etc.).

- The extent to which the political actors in the country are supportive of democratic processes and are willing to prioritise a good process over achieving outcomes that favours them.

Key actors that fund and/or implement electoral assistance include: UN, EU, Organization for Security and Cooperation in Europe (OSCE), the African Union, Inter-American Development Bank, Organization for Economic Cooperation and Development (OECD), Organization for American States (OAS), International IDEA, Inter-Parliamentary Union, Community of Democracies, World Association of Electoral Bodies (A-WEB); US; Germany, UK, the Netherlands; Australia, Sweden, Norway, and Canada (Norris, 2017). In the current day, almost "every Western government gives some aid for electoral assistance, whether through its foreign ministry, bilateral-aid agency, or other institutions" (Norris, 2017). Yet while many bilateral donors also carry out some work in this area, "almost all major electoral support programmes are provided jointly with international partners" (DFID, 2014, p.5).

Donors work with a dense network of actors in implementation, advocacy, research and monitoring, with different actors engaged at different stages of the electoral cycle, for example, election management bodies (EMBs), official government regulatory agencies, 
political parties, legislatures, parliaments, judiciary, national media, social media, social movements, advocacy organisations, grassroots pressure groups, and think tanks (Norris, 2017, p.51). In particular, donors work with a range of international and national non-governmental organisations in implementation, for example: ACE Electoral Knowledge, International IDEA, the US National Endowment for Democracy (NED), the Asian Network for Free Elections (ANFREL), the International Foundation for Electoral Systems (IFES), the Carter Center, Democracy International, Transparency International, the Open Society Institute, the Electoral Institute for Sustainable Democracy in Africa (EISA), the World Movement for Democracy, the Netherlands Institute for Multiparty Democracy (NIMD), the Oslo Centre for Peace and Human Rights, the Danish Institute for Parties and Democracy, Amnesty International, Human Rights Watch, the Open Society Foundation, the Hans Seidel Foundation, the Ford Foundation, the Bertelsmann Foundation, the Carter Center, the Konrad-Adenauer-Stiftung, and Freedom House (Norris, 2017, p.51). Many of the international think tanks and advocacy groups have local branches in countries.

\section{Norris (2017, p.54) identifies types of interventions as including:}

- Establishing rules meeting international standards by reforming the constitutional principles, legal policies and regulatory framework governing elections;

- Implementing policies by building capacity, which enables official agencies to carry out these policies;

- Ensuring compliance by strengthening independent oversight and accountability mechanisms, especially through parliament and the judiciary, and

- Monitoring performance by expanding transparency through international observer missions, comparative indicators, and domestic watchdog agencies.

\section{Electoral assistance programmes may be initiated with electoral needs assessment missions led by the United Nations Electoral Assistance Division (UNEAD), and UNDP, and in some cases also the European Commission (ACE, n.d.a). This can support more} coherent and coordinated approaches among donors, based on broad discussions with the full spectrum of actors that engage in electoral cycle work, and also on reflections of post-election reviews and recommendations (ACE, n.d.a). Yet the "most neglected component of electoral assistance programmes remains monitoring and evaluation. This is partly due to the objective difficulty of evaluating progress in the partner country's democratisation process in the shortterm. Even so, the electoral cycle approach offers a platform to development agencies to remain engaged in a continuous manner throughout this delicate process, where important breakthroughs can be achieved in improving the quality of the ensuing phase of assistance" (ACE, n.d.a). In fragile and conflict affected states (FCAS) elections, conflict sensitive programme design is essential to support peacebuilding and, at a minimum, to do no harm (FathLihic \& Brancati, 2017).

\section{Examples of donor electoral assistance programmes}

\section{UN}

The UN is the biggest actor in electoral assistance programming. More than 100 countries have requested and received UN electoral assistance since 1991 (UN Department of Political and 
Peacebuilding Affairs [UN DPPA], n.d.), with half of all elections held outside of established democracies between 2007 and 2014 receiving UN assistance (Lührmann, 2016). Most UN assistance results from the request of a Member State, and less commonly in cases of peacekeeping or special political missions, it results from a mandate from the Security Council or the General Assembly (UN DPPA, n.d.). Electoral assistance is part of broader UN programming on democratic consolidation and governance, expanding civic participation, strengthening government accountability, conflict prevention, peaceful transitions, the rule of law, human rights, and gender equality (Norris, 2017). Its overarching objectives are derived from the 2015 SDGs, particularly, SDG 16 - promoting peaceful and inclusive societies for sustainable development, providing access to justice for all and building effective, accountable and inclusive institutions at all levels (UN Department of Economic and Social Affairs [UN DESA], n.d.). A number of UN agencies are involved in electoral assistance activities, for example (UN DPPA, n.d.; Norris, 2017; UNDP, n.d.):

- The Electoral Assistance Division (UN-EAD) of the UN DPPA: UN-EAD is the focal point within the UN system for electoral assistance it: works to ensure system-wide coherence and consistency in the provision of UN electoral assistance; recommends the parameters for UN electoral assistance according to the request made by the recipient country and an electoral needs assessment; advises on the electoral mission design or assistance projects; provides an institutional memory of activities and a roster of experts; is responsible for policy development; provides political and technical guidance to UN agencies involved in electoral assistance; provides support to the UN Secretary-General (UNSG) and its envoys, and to UN political and peacekeeping missions in the prevention and mediation of electoral crises; it maintains electoral partnerships with, and provides capacity development support to, other regional and intergovernmental organisations involved in elections; and it oversees field-based special political missions that in many cases engage in electoral assistance activities as part of their conflict prevention or peace-building mandates.

- The United Nations Development Programme (UNDP): UNDP is the major implementing body for the UN agencies outside the peacekeeping or post-conflict contexts, providing electoral assistance activities to 60 countries each year, on average including in FCAS. It: provides support to develop electoral institutions, legal frameworks, and processes; works with Member States and local national partners on long-term capacity development, including the strengthening of electoral management bodies between elections and legal reforms; produces analysis on election-related issues; implements systems for election planning, monitoring and budgeting, supporting voter and civic education, coordinating electoral assistance among donors, promoting political participation of vulnerable and marginalised groups, including women, and in preventing electoral conflict and violence.

- The Department of Peace Operations (DPO): In peacekeeping and many post-conflict situations, assistance is provided through electoral components of field missions under the aegis of the DPO and in collaboration with the Electoral Assistance Division.

- The Office of the High Commissioner for Human Rights (OHCHR): The OHCHR provides training and advice on human rights monitoring in the context of elections, supports and organises campaigns for violence-free elections, engages in advocacy for human rights-compliant electoral laws and institutions, monitors and reports on human rights violations during electoral processes. 
- United Nations Volunteers (UNV): The UNV programme provides substantive and operational support for UN electoral operations, complementing the staffing of such operations, often in large numbers, and in short deployment time frames.

- The United Nations Office for Project Services (UNOPS): UNOPS (a service provider to the UN system and Member States) provides operational, logistical and other support to electoral assistance and often works in close cooperation with UNDP on electoral assistance activities.

- The United Nations Educational, Scientific and Cultural Organization (UNESCO): UNESCO (a UN specialised agency) works to strengthen the capacity of local journalists and media, including providing training and capacity development on elections reporting, to support freedom of expression, press freedom and freedom of information.

- The United Nations Entity for Gender Equality and the Empowerment of Women (UN-Women): UN-Women provides guidance, technical support, and capacity development on gender equality, the empowerment and rights of women, and gender mainstreaming. It promotes gender equality and women's participation in political processes. It also leads, coordinates and promotes the accountability of the UN system in its work on gender equality and the empowerment of women.

- The International Organization for Migration (IOM): IOM implements out-of-country voting for refugees, asylum seekers and migrants.

Other agencies involved in election assistance include: the United Nations Democracy Fund (UNDEF); UN Peace-building Fund, and UN DESA.

UN electoral support programmes are designed according to the context/needs and can include (UN DPPA, n.d.):

- Technical Assistance: The most frequent form of UN support, technical assistance can include legal, operational and logistic assistance. It can cover all, or some, aspects of the electoral process, and can be focussed on one electoral event or can be long term. UN technical assistance focuses primarily on election administration and institutions, yet it may also include assistance to a number of other stakeholders and institutions;

- Support to creating a conducive environment for elections: This is often included in the mandate of UN peace operations. It may include activities that draw on: the UN's military, police and civilian presences to help stabilise the security situation; the OHCHR or UN Women for human rights' monitoring, or the DPPA's mediation or conflict prevention work for peace-making and preventive diplomacy;

- Organisation and conduct of an electoral process: Very exceptionally in special postconflict or decolonisation situations, the UN can be mandated to organise and conduct an election or referendum, a role normally provided by national electoral authorities;

- Certification/verification: Quite exceptionally, the UN can be mandated to play a "certification" role in approving and certifying the credibility of election results, a role normally provided by national electoral authorities;

- Electoral observation: Rarely, the UN can be mandated to conduct electoral observation, where it deploys a mission to observe each phase of an electoral process and report back to the UNSG, who will issue a public statement on the conduct of the election;

- Supervision of elections: Rarely, the UN can be mandated to carry out supervision of elections where it may work directly in establishing the mechanisms of the election, 
and/or make recommendations and endorsements to the national electoral management body.

- Panels of political and/or electoral experts: UN panels entail the deployment of a small team to follow and report on an electoral process. Unlike observation missions, panels are not necessarily present in the country throughout a process and may not make their findings public.

- Coordination of electoral observers: UN support to international observers is of two types: (i) Operational Support, and (ii) Coordination of International Observers. Coordination of international observers involves a wide range of activities that can include the provision of logistics and administrative support to the election observation effort and other additional activities such as briefing and facilitation of the deployment of observers, debriefing, etc.

\section{EU}

The EU is a key actor in electoral assistance and observation. Between 2014 and 2016 it spent $13 \%$ of its development aid budget on actions supporting government and civil society. As an example, the European Instrument for the Promotion of Democracy and Human Rights spent about USD 176 million a year on civil society promotion in recent years, finds Norris (2017). A number of EU institutions, agencies, and actors contribute to electoral assistance work including: the European External Action Service, the European Commission, the Council and the Member States, EU Special Representative for Human Rights (EUSR), the European Parliament, the European Instrument for Democracy and Human Rights (EIDHR), the European Neighbourhood Instrument (ENI), the Development Cooperation Instrument (DCI), European Development Fund (EDF), Instrument contributing to Stability and Peace (ICSP), with the EU's 140 EU Delegations and Offices around the world and Member States Embassies at the forefront of implementation (European Commission, 2020). Global, EU-based and national civil society organisations are also key partners (European Parliament, 2020; European Commission, 2020). All activities are designed in-line with the local context and needs.

Its 2020-24 action plan on human rights and democracy summarises its instruments for its work as (European Commission, 2020, p.1-2):

- Political, human rights and sectoral policy dialogues with partner countries and regional organisations;

- Dialogue and monitoring missions to implement the EU's generalised scheme of preferences (GSP);

- Thematic and geographical instruments under the 2021-2027 multiannual financial framework (specific project and programme arrangements will depend on the context);

- Actions in multilateral and regional human rights fora: EU-led thematic and geographical resolutions that address a wide range of human rights issues, support for other relevant resolutions, EU statements and interventions, participation in interactive dialogues, public debates and briefings, events in support of human rights and democracy;

- Speaking up for human rights and democracy: public diplomacy and communication activities, awareness-raising campaigns, public statements and démarches condemning human rights violations and abuses, and recognising steps taken to promote and protect human rights; 
- Observing trials of human rights defenders;

- The 13 EU human rights guidelines - instruments and tools for EU Delegations and Member States Embassies to advance EU human rights policies;

- Election observation and its follow-up;

- Regular dialogue with civil society, human rights organisations and the business sector, and

- Cooperation and coordination with multilateral human rights institutions and United Nations (UN) human rights treaty bodies.

Its 2020-24 action plan identifies five high-level areas for its new strategy ${ }^{4}$ and provides a little more detail on its broad priorities (European Commission, 2020):

I. Protecting and empowering individuals:

a. Means of implementation: political dialogues; human rights dialogues; sectoral policy dialogues, GSP+ / 'everything but arms' (EBA) monitoring missions; use of the relevant EU human rights guidelines with specific tools to achieve thematic objectives; resolutions in the UN Human Rights Council and the UN General Assembly (UNGA) Third Committee; thematic and geographical financial instruments (relevant programmes and projects); direct support for human rights defenders; trial monitoring; advocacy for ratification and implementation of relevant UN and International Labour Organisation (ILO) conventions and optional protocols; statements on human rights abuses and violations; public diplomacy and targeted campaigns, conferences and other events; dialogue with civil society and other non-state actors.

b. Broad priorities: Protecting people, eliminating inequalities, discrimination and exclusion; empowering people; promoting fundamental freedoms and strengthening civic and political space; supporting the rule of law and the fair administration of justice; and reinforcing economic, social, cultural and labour rights

II. Building resilient, inclusive and democratic societies;

a. Means of implementation: political dialogues; human rights dialogues; electoral observation missions and their follow-up; common security and defence policy (CSDP) civilian and military missions; targeted training for EU staff in Delegations; use of the relevant EU human rights guidelines, with specific tools to achieve thematic objectives; thematic resolutions in the UN Human Rights Council and the UNGA Third Committee; thematic and geographical financial instruments (relevant programmes and projects); advocacy for ratification and implementation of relevant UN conventions and optional protocols; statements on human rights abuses and violations; public diplomacy and targeted campaigns, conferences and other events; dialogue with civil society and other non-state actors.

\footnotetext{
${ }^{4}$ The EU's previous strategy for global electoral assistance and observation, created in 2011, is available here https://eur-lex.europa.eu/summary/EN/legissum:r10105
}

For more information on EU election observation, see here - https://eeas.europa.eu/topics/election-observationmissions-eueoms/421/election-observation-missions-eueoms_en 
b. Broad priorities: Enhancing democratic, accountable and transparent institutions; promoting responsive, inclusive, participatory and representative decisionmaking; supporting independent and pluralistic media, access to information and the fight against disinformation; and reinforcing a human rights and participative approach to conflict prevention and crisis resolution.

III. Promoting a global system for human rights and democracy;

a. Means of implementation: political dialogues; human rights dialogues; sectoral policy dialogues, GSP+/EBA monitoring missions; thematic and geographical resolutions in the UN Human Rights Council and the UNGA Third Committee; thematic and geographical financial instruments (relevant programmes and projects); advocacy for ratification and implementation of relevant UN and ILO conventions and optional protocols; advocacy for increased attention to the impacts of environmental degradation and climate change, on human rights; targeted training for EU staff in Delegations; toolbox: a rights-based approach, encompassing all human rights for EU development cooperation; statements on human rights abuses and violations; démarches; public diplomacy and targeted campaigns, conferences and other events; dialogue with civil society, other nonstate actors and the business sector.

b. Broad priorities: Multilateral cooperation; regional partnerships; bilateral cooperation; civil society and national human rights institutions; business sector; and compliance with international human rights and humanitarian law

IV. New technologies: harnessing opportunities and addressing challenges; and

a. Means of implementation: political dialogues; human rights dialogues; thematic and geographical financial instruments (relevant programmes and projects); multilateral and regional engagement; targeted training for EU staff in Delegations; public diplomacy and targeted campaigns, conferences and other events; dialogue with civil society, other non-state actors and the business sector.

b. Broad priorities: Capacity-building and monitoring; and promoting human rights and democracy in the use of digital technologies, including artificial intelligence;

V. Delivering by working together.

a. Broad priorities: Implementation and evaluation; and public diplomacy and strategic communication

\section{US}

The US is significant provider of electoral assistance, and most of its budget is implemented by USAID (USAID, 2019; Norris, 2017). For example, since 1990, it has carried out democracy and governance programmes in approximately 120 countries and territories, with an estimated USD 8.47 billion budget (Norris, 2017). More specifically to electoral support, since 2006 through its Elections and Political Processes (EPP) Fund it has provided support to 86 countries or regions, with a budget of more than USD 328 million (USAID, 2020b). USAID's electoral assistance support comes under its democracy, human rights and governance strategy (DRG), and this work is overseen by its Center of Excellence on Democracy, Human Rights and Governance (DRG Center) (USAID, 2020a). USAID prioritises integrating its DRG work throughout its core development work, focusing on strengthening and promoting human rights, access to justice, accountable and transparent governance, and an independent and politically active civil society across its work. 
USAID's DRG work is focused on (USAID, 2020a):

- Democratic Governance - Building open, responsive, and accountable institutions and processes that serve the needs and preferences of the public;

- Participation and Inclusion - Ensuring that all have the opportunity to participate and have a voice in how they will be governed;

- Fair Competition, Transparency, and Accountability - Promoting free, transparent and fair political competition so that citizens' preferences are represented;

- Civil Society and Independent Media - Defending citizens' rights of association and expression, so that they can play a role in their country's future;

- Justice and Security - strengthening justice and security institutions, justice and security reforms, holding institutions and people accountable to the rule of law, and, providing access to justice mechanisms;

- Human Rights and Non-discrimination - Supporting efforts to prevent human rights abuses, protect human rights defenders and respond to human rights abuses, and

- Emerging Young Leaders - Building a continuum of civic education, engagement and leadership for young women and young men.

The DRG Center provides: technical advice and support to USAID missions implementing DRG programmes; generates and disseminates knowledge to build the evidence base for global advancement in the area; it also elevates the role of DRG in key USAID, US Government, and multilateral strategies (USAID, 2020a).

USAID's (2013) DRG strategy has four broad objectives:

- Promote participatory, representative and inclusive political processes and government institutions;

- Foster greater accountability of institutions and leaders to citizens and to the law;

- Protect and promote universally recognised human rights, and

- Improve development outcomes through the integration of DRG principles and practices across USAID's development portfolio.

UK

The UK's work around electoral assistance comes under its broad work on "fair power structures" (set out in the Building Stability Framework (Department for International Development (DFID), 2016)), and "Strengthening global peace, security and governance" (set out in the UK Aid Strategy (HM Treasury \& DFID, 2015)). Both documents list this as the first of a number of strategic priorities. Previously led by DFID, the UK's work in this area is now being redesigned due to the merger of its government departments DFID and the Foreign and Commonwealth Office (FCO).

UK support to elections has involved different combinations of diplomatic, technical and financial support (DFID, 2014). A policy document by DFID (2014) explains how the exact scale and composition of UK assistance to the electoral cycle has varied substantially, depending on the country context. For example, in aid-dependent and post-conflict countries, UK support would be provided jointly with other international partners, and should form part of a broader, multi-annual 
approach to supporting the democratic process; while for countries that are not aid-dependent, the UK may choose to make discrete investments from the development budget, the Conflict Pools or other UK funds to support particular election-related processes or activities (DFID, 2014). Alternatively, it may engage only at a diplomatic level to reinforce democratic norms and manage tensions. The note highlights that "There are many ways we can support this process of democratic consolidation, including working with parliaments, judiciaries, accountability institutions and civil society. Electoral assistance is one of the options available" (DFID, 2014, p.1).

\section{Germany}

Germany has agreed with more than half of its partner countries to make "Democracy, civil society, governance" a priority area of its development cooperation (BMZ, n.d.), and work on SDG 16 is one of its five core areas in its 2030 strategy (BMZ, 2020), however no explicit reference to electoral cycles or interventions is made. This rapid review found little information online, however the BMZ (n.d.) webpage mentions the following objectives/themes in this broad area:

- Political reform processes: The aim is to increase the legitimacy and transparency of government actions and to improve supervision of how power is exercised;

- Protecting, respecting and ensuring human rights;

- Promoting freedom of opinion and freedom of the press;

- Combating corruption and abuse of office;

- Strengthening socially disadvantaged sections of the population and making political participation possible for them;

- Promoting political participation, by:

- Strengthening civil society by supporting the establishment of civil society organisations and political participation by the people,

- Improving state effectiveness by, for instance, enabling state actors to deal with public participation in a competent manner, and

- Creating public institutions and a legal basis to facilitate political participation;

- Cooperation with state and non-state actors, and

- Multilateral cooperation, including through UN and EU programmes, aimed at promoting democratisation.

While no explicit reference to electoral cycles or systems is made on this high-level summary of Germany's international development work, there are examples online, at the country-level, where Germany has provided electoral assistance funding - e.g. contributing funding to a UN capacity-building project within the Iraqi Independent High Electoral Commission (UNAMI, 2020). 


\section{References}

ACE Electoral Knowledge Network (ACE) (n.d.a) Electoral Assistance [Webpage] Ace https://aceproject.org/ace-en/focus/focus-on-effective-electoral-assistance/onePage

ACE (n.d.b) Media and elections [Webpage] Ace https://aceproject.org/aceen $/$ topics $/ \mathrm{me} / \mathrm{med} / \mathrm{med0} / \mathrm{med06} /$ default

ACE (n.d.c) Preventing Election-related Violence [Webpage] Ace https://aceproject.org/aceen/topics/ev/prevention-and-mitigation/ev301/planning-and-preparation-for-the-implementationof)

ACE (n.d.d) Gender and elections [Webpage] Ace https://aceproject.org/aceen/topics/ge/ge5/default

ACE (n.d.e.) Electoral assistance [Webpage] Ace https://aceproject.org/electoraladvice/electoral-assistance

BMZ (2020) BMZ 2030 reform strategy: New thinking - new direction. BMZ. https://www.bmz.de/en/publications/type_of_publication/information_flyer/information_brochures/ Materilie520_reform_strategy.pdf

BMZ (n.d.) Germany's contribution Strengthening democracy: one of the tasks of German development policy [Webpage] BMZ.

https://www.bmz.de/en/issues/demokratie/arbeitsfelder/index.html

Cheeseman, N. \& Dodsworth, S. (2019) The observation of new electoral technologies. Open Society European Policy Institute. Internal document

DFID (2014) How to note: On Electoral Assistance. Version 2.0. DFID

https://assets.publishing.service.gov.uk/government/uploads/system/uploads/attachment_data/fil e/67651/how-to-on-elect-asst.pdf

DFID (2016) Building Stability Framework. DFID.

https://assets. publishing.service.gov.uk/media/5968990ded915d0baf00019e/UK-Aid-ConnectStability-Framework.pdf

European Commission (2020) ANNEX to the JOINT COMMUNICATION TO THE EUROPEAN PARLIAMENT AND THE COUNCIL. EU Action Plan on Human Rights and Democracy 2020 2024. European Commission. https://ec.europa.eu/info/law/better-regulation/have-yoursay/initiatives/12122-EU-Action-Plan-on-Human-Rights-and-Democracy-2020-2024

European Parliament (2020) Promoting democracy and observing elections [Webpage] European Parliament https://www.europarl.europa.eu/factsheets/en/sheet/166/promotingdemocracy-and-observing-elections

Fath-Lihic, A. M. \& Brancati, D. (2017). Elections and Peacebuilding: Why the timing and sequencing of transitional elections matter. Policy brief No.4. Kofi Annan Foundation http://www.kofiannanfoundation.org/app/uploads/2017/05/Elections-and-Peacebuilding.pdf

Haider, H. (2008) Helpdesk Research Report: Electoral Assistance. Lessons.

https://gsdrc.org/publications/electoral-assistance-lessons/ 
Haider, H. (2011) Helpdesk Research Report: Electoral support interventions http://www.gsdrc.org/docs/open/hdq770.pdf

HM Treasury \& DFID (2015) UK aid: tackling global challenges in the national interest. HM Treasury \& DFID https://www.gov.uk/government/publications/uk-aid-tackling-global-challengesin-the-national-interest

Norris, P. (2017). What Is Electoral Assistance? In Strengthening Electoral Integrity (pp. 31-32). Cambridge: Cambridge University Press. doi:10.1017/9781107280656.003 https://www.cambridge.org/core/books/strengthening-electoral-integrity/what-is-electoralassistance/F18251AE5FA1D474987F82A5168C21DF

The United Nations Assistance Mission for Iraq (UNAMI) (2020) UN signs financing agreement with Germany to support UN electoral assistance to Iraq. [Press release] Relief Web. https://reliefweb.int/report/iraq/un-signs-financing-agreement-germany-support-un-electoralassistance-iraq-enarku

UN Department of Economic and Social Affairs (UN DESA) (n.d.). Goals. 16: Promote peaceful and inclusive societies for sustainable development, provide access to justice for all and build effective, accountable and inclusive institutions at all levels. [Webpage] UN DESA https://sdgs.un.org/goals/goal16

UN Department of Political and Peacebuilding Affairs (UN DPPA). (n.d.). Elections. [Webpage] UN DPPA. https://dppa.un.org/en/elections

UNDP \& UN Women (2015) Inclusive Electoral Processes: A Guide for Electoral Management Bodies on Promoting Gender Equality and Women's Participation. UNDP \& UN Women https://www.undp.org/content/undp/en/home/librarypage/democraticgovernance/electoral_systemsandprocesses/guide-for-electoral-management-bodies-onpromoting-gender-equali.html

UNDP (n.d.) Electoral cycle support. [Webpage] UNDP https://www.undp.org/content/undp/en/home/2030-agenda-for-sustainabledevelopment/peace/governance/electoral-cycle-support.html

USAID (2013) Strategy on democracy human rights and governance. USAID https://www.usaid.gov/democracy-human-rights-and-governance-strategy

USAID (2019) User's guide to democracy, human rights and governance programming. USAID https://www.usaid.gov/sites/default/files/documents/1866/DRG-Users-Guide-3.15.2019.pdf

USAID (2019) User's guide to democracy,human rights and governance programming. USAID https://www.usaid.gov/documents/1866/users-guide-democracy-human-rights-and-governanceprogramming

USAID (2020a) Democracy, human rights and governance. [Webpage] USAID https://www.usaid.gov/democracy

USAID (2020b) Center of excellence on democracy, human rights and governance. [Webpage] https://www.usaid.gov/who-we-are/organization/bureaus/bureau-democracy-conflict-andhumanitarian-assistance/center 


\section{Acknowledgements}

We thank the following experts who voluntarily provided suggestions for relevant literature or other advice to the author to support the preparation of this report. The content of the report does not necessarily reflect the opinions of any of the experts consulted.

- Nic Cheeseman, University of Birmingham

- Guy Grossman, University of Pennsylvania

- Susan D. Hyde, University of California, Berkeley

\section{Suggested citation}

Herbert, S. (2021). Donor support to electoral cycles. K4D Helpdesk Report. Brighton, UK: Institute of Development Studies. DOI: 10.19088/K4D.2021.043

\section{About this report}

This report is based on six days of desk-based research. The K4D research helpdesk provides rapid syntheses of a selection of recent relevant literature and international expert thinking in response to specific questions relating to international development. For any enquiries, contact helpdesk@k4d.info.

K4D services are provided by a consortium of leading organisations working in international development, led by the Institute of Development Studies (IDS), with Education Development Trust, Itad, University of Leeds Nuffield Centre for International Health and Development, Liverpool School of Tropical Medicine (LSTM), University of Birmingham International Development Department (IDD) and the University of Manchester Humanitarian and Conflict Response Institute (HCRI).

This report was prepared for the UK Government's Foreign, Commonwealth and Development Office (FCDO) and its partners in support of pro-poor programmes. Except where otherwise stated, it is licensed for non-commercial purposes under the terms of the Open Government Licence v3.0. K4D cannot be held responsible for errors, omissions or any consequences arising from the use of information contained in this report. Any views and opinions expressed do not necessarily reflect those of FCDO, K4D or any other contributing organisation.

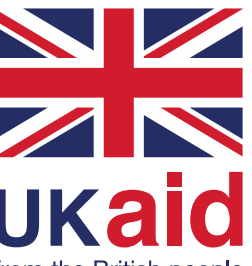

(c) Crown copyright 2021. 